ERC Working Papers in Economics 15/12

December / 2015

\title{
Intergenerational Educational Mobility in Turkey
}

\author{
Aysit Tansel \\ Department of Economics, Middle East Technical University, Ankara, Turkey and \\ Institute for the Study of Labor (IZA) Bonn, Germany and \\ Economic Research Forum (ERF) Cairo, Egypt \\ E-mail: atansel@ metu.edu.tr \\ Phone: + (90) 3122102073
}




\title{
INTERGENERATIONAL EDUCATIONAL MOBILITY IN TURKEY*
}

\author{
Aysit Tansel \\ Department of Economics \\ Middle East Technical University, 06800 Ankara, Turkey \\ Telephone: 903122102057 \\ Fax: 903122107957 \\ E-mail: atansel@metu.edu.tr \\ Institute for the Study of Labor (IZA), Bonn, Germany \\ Economic Research Forum (ERF), Cairo, Egypt
}

\section{December 12, 2011}

\begin{abstract}
This paper aims to provide information on intergenerational educational mobility in Turkey over the last century (at least over the last 65 years). This is the first study explicitly on providing the association between parents' and children's education in Turkey over time unlike the previous studies of one point in time. Given the absence of longitudinal data, we make use of a unique data set on educational outcomes based on children recall of parental education. The data used is the result of Adult Education Survey of 2007. Several findings emerge from the analysis. First of all, children's and parents' educational outcomes are correlated. The intergenerational educational coefficient of the mothers is somewhat larger than that of the fathers. The intergenerational educational coefficients of both the mothers and the fathers decrease over the cohorts implying that intergenerational educational mobility increased significantly for the younger generations of children in Turkey. The chances of attaining a university degree for the children increases as fathers' completed schooling level increases. Men's chances of attaining high school or university education are substantially higher than that of women's. The association between parent and child education is stronger when parent educational background is poor. The results imply that the policy makes should focus on children with poor parental educational background and on women.
\end{abstract}

Key Words: intergenerational mobility, educational transmission, Turkey

JEL Classification: I21, I28, J11, J62

\footnotetext{
*This paper is written during my visit at the Industrial and Labor Relations School, Cornell University, Ithaca, New York, USA during the academic year 2011-2012. I gratefully acknowledge the support of Fulbright Fellowship during my visit at the Cornell University. This paper was presented at the Economics of Education Seminar, Cornell University, Ithaca NY USA, 15 December, 2011, at the annual meeting of the Middle East Economic Association, Chicago, Illinois, USA, 5-8 January 2012, at the Department of Economics, Binghamton University, Binghamton, NY, USA, 3 February 2012, and at the ICE-TEA (International Economics Conference-Turkish Economics Association) Izmir, Turkey, November 2012. I have benefited from the comments of the participants at these meetings. I would also like to thank Antonio Di Paolo for his suggestions.Any errors are my own.
} 


\section{INTRODUCTION}

Economic and social mobility in any society is a desirable attribute. This is true both from the point of the individual and of the society. Lack of intergenerational economic and social mobility in a society should be of concern for at least three reasons. First of all, intergenerational mobility can be seen as a measure of equality of opportunity. There will be more social integration if individuals believe that they will succeed through their own efforts and abilities. Recently, equality of opportunity is a growing concern in both developed and developing countries. Access to education is an important policy instrument to ensure equality of opportunity. As it is well known one aim of the free publicly provided education in most societies is to increase equality of opportunity.

The second argument is on economic efficiency grounds. Lack of intergenerational mobility leads to economic inefficiency since some individuals' abilities and skills would be underutilized or miss-utilized.

The third argument is on overall social welfare grounds. Intergenerational allocation of resources has implications for the overall social welfare and for poverty and inequality. For these reasons we need to be concerned about the degree of economic and social mobility between generations.

Intergenerational mobility studies concentrate on how children's income or education correlates with the income, occupation or education of their parents. This study deals with the intergenerational mobility in educational outcomes using educational attainments of parents and their children. Perfect educational mobility between generations implies that an individual's educational outcome is independent of his/her parents' educational outcome. This will be an indicator of equality of opportunity.

Most studies on intergenerational mobility focus on developed countries. The studies on this topic in developing countries are limited due to lack of appropriate data sets. Income and occupational mobility as well as educational mobility are popular topics of study in developed countries. Educational mobility could be a good proxy for income mobility since income is highly dependent on education. 
There is no evidence on the extent of intergenerational mobility in Turkey except the study by Tansel (2002) which examines one point in time. This is due to the lack of longitudinal data to analyze income mobility or educational mobility. This paper aims to provide information on intergenerational educational mobility in Turkey over time which is not addressed previously. This is the first study about parent-child education transmission over time for Turkey covering a period of about 65 years. Given the absence of longitudinal data, we make use of a unique data set on educational outcomes based on children recall of parental education. This analysis provides both current evidence as well as a long term perspective on the parent-child education transmission. The study tests whether the impact of parental background on child educational outcomes have changed over time. The data used is the result of Adult Education Survey of 2007. The survey is conducted by the Turkish Statistical Institute (TURKSTAT). There are 39,478 individuals who provided information about their own education level and that of their parents.

This study first provides educational transition matrices and several educational mobility indicators. Next regression analysis is used to estimate correlations between educational outcomes of children and that of their parents'. Finally, ordered probit models are estimated. The results show that children's and parents' educational outcomes are correlated and that mothers' education is somewhat more important than that of the fathers'. Further there is substantial intergenerational educational mobility over time when regression coefficient is used however the pattern is less clear when correlation coefficient is used. Predicted probabilities of educational attainment by fathers' educational background are also presented and discussed. The chances of attaining a university degree for the children increases as fathers' completed schooling level increases. Men's chances of attaining high school or university education are substantially higher than that of women's at all levels of the parental educational background. The association between parent and child education is stronger when parent educational background is poor. The results imply that the policy makes should focus on children with poor parental educational background and on women.

This paper is organized as follows. Section 2 includes a summary of recent literature. The educational system in Turkey and the data used in this study are introduced in Section 3. The 
educational transition matrices and several measures of educational mobility are provided in Section 4. Section 5 presents the OLS estimates of the intergenerational educational coefficients. The ordered probit estimates and predicted probabilities are presented in Section 6. Section 7 gives conclusions and policy implications.

\section{PREVIOUS LITERATURE}

The research on intergenerational educational mobility is voluminous. It has developed on two strands. The earlier research concentrated on estimating the intergenerational regression and correlation coefficients and refining their estimation. Recent research focused on isolating the causal effect of parental education on the child education. In the examination of the inheritable persistence in the effects of parents' education on the children's schooling recent studies have employed data sets using variation within siblings, within fraternal and identical twins, and adopteesor IV estimation. Among these studies we can cite Rosenzweig and Wolpin, 1994; Sacerdote, 2002; Behrman and Rosenzweig, 2002; Plug and Vijverberg, 2003; Plug, 2004. Behrman and Rosenzweig use a sample of twins. Plug uses a sample of adoptees. Most of these studies find that parental education has at least a small impact on children's schooling. Another group of studies uses instrumental variable estimates in order to deal with the endogeneity of the parental education. Chevalier (2003) uses the 1973 compulsory education law in Great Britain as a source of exogenous variation in parental education. He finds that while father's schooling has no significant effect the mother's schooling has a positive effect on the probability of children's post-compulsory education. Oreopoulos, Page and Stevens (2006) use IV estimation with historical changes in compulsory schooling legislation in the USA and find that an increase in the schooling of either parent reduces the probability that a child repeats a grade and that 15-16 year olds will drop out of school. However, some studies find no statistically significant relationships when IV estimation is employed. For instance, Black, Devereux, and Salvanes (2005) use IV estimation with multiple changes in compulsory schooling laws in Norway and do not find a statistically significant relationship between parental education and children's schooling. Silles (2011) presents evidence on the effect of parental schooling on children's cognitive and non- cognitive development in the UK. She finds that the OLS estimates are 
positive and statistically significant. However when she employs exogenous increases in schooling induced by the schooling reform of 1947 in the UK the statistically significant relationship disappears.

Hertz et al. (2007) examine the intergenerational transmission of education for 42 countries. Nimubona and Vencatachellum (2007) investigate the intergenerational educational mobility in South Africa and review the literature on educational correlations. They find that the cross section estimates of black intergenerational education mobility do not differ from those obtained by using pseudo-panel data, which control for unobserved community effects. Their results indicate that intergenerational education mobility of whites is higher than that of blacks. Further among the blacks females have higher intergenerational education mobility than males and the poor have the lowest intergenerational educational mobility.

Daouli et al. (2010) investigate the intergenerational educational mobility in Greece for daughters using conventional methods of transition matrices and intergenerational educational coefficients as well as probit model estimates. Their results indicate substantial intergenerational educational mobility in Greece.

\section{EDUCATIONAL SYSTEM IN TURKEY AND THE DATA}

Since the establishment of the Republic of Turkey in 1923 education of the population received great attention and was free of tuition or fees at all levels. In the early 1960's there was a major attempt to expand coverage. Until 1997 the educational system consisted of primary school of five years, middle school of three years, and high school of three years and tertiary levels of schooling. Five years of primary schooling was the only compulsory level of schooling until 1997. High schools encompass general, vocational and technical high schools. In 1997 there was a major educational reform which extended the compulsory education from five to eight years covering middle school. This affected pupils born after 1987. In the following period high schools are extended from three years to four years. Tertiary education takes place at the universities with two or four or more years of programs. The two year programs provide associate degrees and the four-six year programs provide bachelor's degrees. The number of 
universities has been increasing over time since the 1990's. Currently there are 165 universities all over the country.

There have been substantial improvements in the educational attainments over time. Adult literacy rate increased from 17 percent in 1960 to 75 percent for females and 93 percent for males in 1998 (World Bank, 2000/2001). 39 percent of the labor force is graduate of primary school of five years. During the 2010-2011 academic year the enrollment ratio at the primary level was $99 \%$ for both boys and girls and at the high school level it was $72 \%$ for boys and $66 \%$ for girls.

Tertiary gross enrollment ratio increased from three percent in 1960 to 16 percent in 1993 (World Bank 1984, 1997). During the 2009-2010 academic year the enrollment ratio was $31 \%$ for men and $30 \%$ percent for women.

The data used in this study comes from the Adult Education Survey conducted in 2007 by the Statistical Institute of Turkey (TURKSTAT). Two stage, stratified, systematic, cluster sampling method is used in sampling design. Classification of Statistical Regional Units and Rural-Urban strata are used as external stratification criterion. Locations with population over 20,000 are defined as urban and locations with population 20,000 or less are defined as rural locations. The survey includes rich information about formal education, informal education, lifelong learning, fields of education and training, conditions that prevent participation in education, computer usage and foreign language skills, cultural activities as well as employment situation and income of the individual. The survey contains information on parental education of all surveyed individuals through the recall of children. This allows identification of the parental education even if the parents and children are not co-resident. There are a total of 39,478 individuals interviewed in 17,501 households. In these households only the individuals 18 years old and over are interviewed face to face. Proxy answers were not allowed. It was possible to distinguish six cohorts representing age groups 18-24, 25-34, 45-54, 55-64 and 65+.

Table 1 shows the distribution of the highest degree completed by cohort for children. 
As can be observed the youngest cohort of individuals (18-24 group) attained the highest levels of education. The oldest cohort (65 and over) have the lowest levels of education. This indicates substantial improvement over time in educational attainments. Table 2 gives the distribution of the highest degree completed by the mothers by cohort. For the cohort of 65 and over the average years of schooling for the mothers is very low. Substantial improvement over time in mother's educational attainment is observed. Table 3 gives the distribution of the highest degree completed by the fathers by cohort. Father's educational attainment is higher than that of mothers for all cohorts. Again the table indicates substantial improvement over time in the educational attainment of the fathers.

\section{EDUCATIONAL TRANSITION MATRICES}

Markov educational transition matrices and several mobility measures are presented in this section. For this purpose four educational categories are distinguished. These are primary or less, middle school, high school and university. Primary or less includes illiterates, literates but not graduate of any school and primary school graduates. Parents' generation represents time period $\mathrm{t}$ and the children's generation represents time period $\mathrm{t}+1$. We let $\mathrm{p}_{\mathrm{ij}}$ show the probability that the educational outcome $\mathrm{i}$ in $\mathrm{t}$ moves to educational outcome $\mathrm{j}$ in $\mathrm{t}+1$. $\mathrm{P}$ denotes the $4 \times 4$ matrix with elements $\mathrm{p}_{\mathrm{ij}}$. The transition matrix is estimated for the total sample covering the period before and including 1942 and 2007. Overall the estimated Markov educational transition matrix indicates substantial stagnation.

There are three mobility indicators used to measure the overall level of mobility. The first is the Prais (1955) and Shorrocks (1978) mobility index denoted by M(PS). It is defined as M(PS)= $(1 /(n-1)(n-\operatorname{tr}(\mathrm{P}))$ where $\mathrm{n}$ is the number of educational outcomes, $\mathrm{P}$ is the observed transition matrix and $\operatorname{tr}(\mathrm{P})$ is its trace. M(PS) takes values between zero and one. The value of one implies perfect mobility and the value of zero implies perfect immobility. Checchi et al. (1999) and Douboli et al. (2010) provide further information on this index. The second indicator is the upward and the third is the downward mobility indicators. The upward mobility indicator is the arithmetic average of the entries below the main diagonal of the $\mathrm{P}$ matrix. The downward 
mobility indicator is the arithmetic average of the entries above the main diagonal of the $\mathrm{P}$ matrix. The arithmetic average of the entries on the main diagonal of the $\mathrm{P}$ matrix gives the immobility ratio. Heineck and Riphahn (2007) and Douboli et al. (2010) provide further information on this index. The third indicator is the relative opportunities mobility indicator which is discussed by Bauer and Riphahn (2007). It shows "the extent to which the observed educational attainment of children are equally distributed across all parental backgrounds" (Douboli et al., 2010). These Mobility Indicators are presented below.

- 1) Prais-Shorrocks (Checchi et al. 1999) $\mathrm{PS}=(1 /(\mathrm{n}-1)(\mathrm{n}-\operatorname{tr}(\mathrm{P})) \mathrm{n}=$ number of states.P is the transition matrix. Tr shows trace. 0 is perfect immobility, 1 is perfect mobility. $\mathrm{PS}=0.0846$ in Turkey, in Greecefor daughters PS=0.663 to 0.870 (Douboli et al., 2010).This indicates high immobility for Turkey.

- 2) Immobility Index (Heineck and Riphanh, 2007; Douboli et al., 2010). IMI=Arithmetic Average of the $\operatorname{tr}(\mathrm{P})$. IMI $=0.4088$ in Turkey, in Greecefor daughters $=0.342$ (Douboli et al., 2010).

- 3) Upward mobility Index: Arithmetic average of the entries below the main diagonal of P. UMI $=0.1995$ in Turkey, in Greece for daughters $=0.215-0.312$ (Douboli et al., 2010).

- 4) Downward Mobility Index: Arithmetic Average of the entries above the main diagonal of P. DMI $=0.1239$ in Turkey, in Greecefor daughters $=0.117-0.048$ (Douboli et al., 2010).

\section{INTERGENERATIONAL EDUCATIONAL COEFFICIENTS}

Table 5 shows the intergenerational educational coefficient. It is the coefficient of the parent's education in the following equation:

$\mathrm{CE}_{\mathrm{i}}=\mathrm{a}+\mathrm{b} \mathrm{PE}_{\mathrm{i}}+\mathrm{E}_{\mathrm{i}}$

CE: Child education.

PE: Mother education or father education.

E: Error term 
A high value of $b$ implies low intergenerational educational mobility and a low value of $b$ implies high intergenerational mobility. A negative value of $\mathrm{b}$ implies educational attainment converges over time.

This equation is estimated for each cohort by OLS method and presented in Table 5.

The estimates in columns 2 and 4 include controls for the gender of the child and region of residence as rural and urban.

There are three observations to note in Table 5.

1) Children's educational attainment is positively affected by parental education as it is also shown by Belzil and Hansen (2003) and Cameron and Heckman (1998). The intergenerational educational coefficient of the mothers seem somewhat larger in magnitude than that of the fathers.

2) The intergenerational educational coefficients of both the mothers and the fathers decrease over the cohorts. This implies intergenerational educational mobility has increased significantly for the younger generations of children.

3) In general the intergenerational educational coefficients are smaller when the equations include controls for gender and region.

We can show that:

$\mathrm{b}=\mathrm{r}\left(\sigma_{\mathrm{c}} / \sigma_{\mathrm{f}}\right)$

Thus, the parameter $\mathrm{b}$ takes the ratio of standard deviations of the children to that of parents into account. Therefore, the change of inequality in educational outcomes over time between the two generations appears in the parameter $b$.

A decreasing $\mathrm{b}$ across the cohorts may be interpreted as an increase in educational mobility. However, it may be due to a reduction in the $\left(\sigma_{\mathrm{c}} / \sigma_{\mathrm{f}}\right)$ over the cohorts. 
Table 4 gives the standard deviations of the educational level of the children, mothers and fathers and their ratios. The ratio of the standard deviation of the children's education to that of their mother's and father's decreases over the cohorts.

Since the ratio of standard deviations decreased through time in Turkey, the parameter estimate of $b$ includes the effect of the educational expansion over time. Therefore, I also estimated the correlation coefficient between parent and child education. Checci et al. (2008) shows that b is a relative measure of intergenerational mobility while the correlation coefficient is an absolute measure of intergenerational mobility. Hertz et al. (2007) show that the evolution of $b$ and the correlation coefficient could differ over time which is what I find in this study also.

Table 6 shows the intergenerational educational Correlation Coefficient estimated from the following equation:

$\left(\mathrm{CE}_{\mathrm{i}} / \sigma_{\mathrm{c}}\right)=\mathrm{a}+\mathrm{r}\left(\mathrm{PE}_{\mathrm{i}} / \sigma_{\mathrm{f}}\right)+\mathrm{E}_{\mathrm{i}}$

Here the $\mathrm{CE}$ and $\mathrm{PE}$ are divided by their respective standard errors. The coefficient $r$ is the correlation coefficient of the children's and parents' education. There is no discernible pattern to the correlation coefficient over time as it is observed in Table 6 This the results in the table indicate no improvement over time in educational mobility in Turkey.

Table 7 shows the Intergenerational Educational Coefficient for mother by educational background. The sample is divided into two according to mother having primary school education or less and higher than primary school. The coefficients for the group of mothers' education is primary or less are higher than for the group of mothers' education post primary. This indicates higher educational persistence for the group of less educated mothers than for the better educated mothers.

Table 8 shows the intergenerational educational coefficient when the sample is divided according to father's education being primary or less and above primary. The coefficients for father primary or less are larger than the coefficients for father post primary indicating higher educational persistence for the group of less educated fathers than for the better educated fathers. 
Tables 7 and 8 imply that there is a stronger relationship between child and parent education when the parent educational background is poor. This result implies that the policy makers should concentrate on helping children with poor parental educational backgrounds.

Table 9 shows the intergenerational educational coefficient by alternative definitions of educational background. The two alternatives used are the average parental schooling and the education level of the parent with the highest education. The coefficients are larger when average parental schooling is used. In both cases the coefficients decline overtime smoothly indicating an increase in the educational mobility over time in Turkey.

Figure 1 shows the expected number of years of education by birth cohort for the levels of father education completed. This figure indicates a persistent gap between individuals and their fathers schooling. Only individuals with tertiary educated father constantly achieve close to 14 years of schooling. Children from the disadvantaged group of fathers who are not a graduate of any school have about 4 years of schooling. However, their schooling attainment is increasing over time.

\section{ORDERED PROBIT MODEL ESTIMATES}

Table 11 presents the estimates of an ordered probit model for the completed education levels categorized into four levels as primary or less, middle school, high school and university education. Primary is taken as the reference category. The model is estimated separately for each birth cohort. Gender takes a value of one for male individuals. Urban takes a value of one for individuals located in urban areas. All of the coefficient estimates are statistically significant.

The parental education background is represented by the highest completed level of education by the father. Father's education is an important determinant of an individual's education. Father primary or less has the lowest impact and the father university has the highest impact on the individual's education. At all education levels the effect of father's education declines over time indicating increased educational mobility. 
The effect of being male on educational attainment is positive, statistically significant and declines over time. This implies that the gender gap in education has declined significantly over time.

The effect of living in an urban location on educational attainment is positive, statistically significant and declines over time. This implies that the rural-urban gap in educational attainment declined over time.

\subsection{PREDICTED PROBABILITIES}

The ordered probit estimates can be used to compute the predicted probability of completing a level of schooling, say university for an individual, born in cohort say 18-24, with father's education say primary or less. This probability describes the educational opportunity of the individual. It is the probability of completing university level education.

We now show the probability of achieving a given level of education for individuals of different father educational background for each birth cohort. These are shown in Figure 2

The figures consider the predicted probabilities of high school and university level education completion. The figures show the predicted probabilities and the $90 \%$ confidence intervals. The confidence intervals are shown with dotted lines. The lines with triangular markers in pink represent the probability of attaining university degree. The lines with square markers in blue represent the probability of attaining high school degree.

The likelihood of completing high school increases across cohorts in all of the four figures which correspond to different father's educational level. In all cases there is greater dispersion in completing the university education than completing the high school education. For the youngest cohort of 18-24 the probability of attaining university education falls probably because this age group is too young yet for university graduation.

Only the individuals whose fathers completed university have the highest probability of completing university of about $70 \%$ in the middle cohorts. 
Only for the individuals whose father is illiterate or primary school graduate, the probability of attaining university degree is lower than the probability of attaining high school degree. In this case the probability of attaining university degree is about $5 \%$.

The probability of attaining a university degree declines as the father's completed schooling level declines. The probability of attaining a university degree is around 70-80\% for those whose fathers have a university degree. This probability goes down to around $45 \%$ for those whose fathers have a high school degree. The same probability goes down to $30 \%$ for those whose fathers have a middle school degree. It is only $5 \%$ for those whose fathers are illiterate or primary school graduate.

\subsection{PREDICTED PROBABILITIES FOR URBAN MEN AND WOMEN}

The next set of four figures give the predicted probabilities for urban men. The following next set of four figures give the predicted probabilities for urban women. Each of the four figures correspond to different level of education for the father. The general shapes of the predicted probabilities for university and high school degrees are similar for men and women. The only difference is that at all levels men's predicted probabilities are higher than that of the women's predicted probabilities.

\section{CONCLUSIONS}

This paper which investigates intergenerational educational mobility over time is the first study in Turkey. Previous studies such as Tansel (2002) addressed this topic for one point in time while the current study provides a perspective over the (at least) last 65 years. For this purpose I use the Adult Education Survey of 2007. This survey provides information on parent education through recall of the children. This identifies parent education even if the parents and children are not co-resident. I estimate the educational transition matrix, mobility indicators, intergenerational educational coefficients and intergenerational educational correlation coefficients by regression analysis. Further ordered probit models of completed education are 
estimated allowing computation of predicted probabilities which describe the educational opportunities across cohorts for different parental educational backgrounds.

The educational attainment of individuals seem somewhat more strongly related to their mother's education than to their father's education. In some cases the mother's and father's educational coefficients are similar in magnitude.

The results show that the intergenerational educational coefficient has declined over time indicating increased educational mobility and improved educational opportunity recently in Turkey. This result is true when regression coefficient is used. The pattern in evolution over time is less clear when correlation coefficient is used. However the association between parent and child education is still strong. In particular, the parent child educational relationship are found to be stronger when parents have poor educational background such as primary education or less compared to post primary educational background. This strong association at poor educational background levels imply that educational policy should in particular target group of children with low parental education levels.

The chances of attaining university degree is higher than the chances of completing high school at all levels of fathers educational background except the education level primary or less for the father. The probability of attaining university degree for a child increases as fathers' completed schooling level increases. The children born to fathers with primary or less education have only 5 percent probability of attaining a university degree while the children born to fathers with a university education have probability of 70-80 percent of completing university education.

One of the important results indicate that at all levels of fathers educational background, men's predicted probabilities of completing high school or the university education are substantially higher than that of the women's.

The results imply that educational policy should target children from low parental educational backgrounds as well as women overall.

Future research will compare earlier and later sub-periods in order to further identify the evolution of mobility over time. Estimations will be carried out separately for male and female children and mother father pairs in order to identify differences in any by gender. 
Decompositions will be carried out in order to explicitly isolate the effect of educational expansion. Finally, different regions of Turkey will be studied to see if there are any regional differences in the educational mobility patterns. 


\section{REFERENCES}

d'Addio, A.C. (2007) "Intergenerational Transmission of Disadvantage: Mobility or Immobility across Generations? A Review of the Evidence for OECD Countries", OECD Social, Employment and Migration Working Paper No: 52.

Aydemir, A., W. H. Chen and M. Corak (2008) "Intergenerational Education Mobility among the Children of Canadian Immigrants", Bonn: Institute for the Study of Labor (IZA) Discussion Paper No: 3759.

Bauer, Philipp and Regina T. Riphahn, (2007) "Heterogeneity in the Intergenerational Transmission of Educational Attainment: Evidence from Switzerland on Natives and Second Generation Immigrants", Journal of Population Economics 20(1), 121-148.

Becker, G.S. (1988) "Family Economics and Macro Behaviors", The American Economic Review, 78: 1-13.

Becker, S. G., and N. Tomes (1986) "Human Capital and the Rise and Fall of Families", Journal of Labor Economics, 4: S1-S39.

Behrman J. (1997) "Mother's Schooling and Child Education: A Survey", University of Pennsylvania, Economics Department, Discussion Paper No: 025.

Behrman, J., and M. Rosenzweig (2002) "Does Increasing Women's Schooling Raise the Schooling of the Next Generation? “, American Economic Review, 92(1): 323-334.

Belzil, C., and J. Hansen (2003) " Structural Estimates of the Intergenerational Education Correlation", Journal of Applied Econometrics, 18(6): 679-696.

Black S. E. and P. J. Devereux (2010) "Recent Developments in Intergenerational Mobility", National Bureau of Economic Research (NBER) Working Paper No: 15889. http://www.nber.org/papers/w15889

Black, Sandra E., Paul J. Devereux, and Kjell G. Salvanes, (2005) "Why the Apple Doesn't Fall Far: Understanding Intergenerational Transmission of Human Capital", American Economic Review 95(1), 437-449

Blanden, Jo, and Stephen Machin (2004) "Educational Inequality and the Expansion of UK Higher Education", Scottish Journal of Political Economy, 51(2), 230-249.

Blanden, Jo, Paul Gregg, and Stephen Machin (2005) "Intergenerational Mobility in Europe and North America", A Report Supported by Sutton Trust, Centre for Economic Performance, London, mimeo.

Cameron, S., and J. Heckman (1998) "Life Cycle Schooling and Dynamic Selection Bias: Models and Evidence for Five Cohorts of American Males", Journal of Political Economy, 106(2), 262-333.

Causa, O., S. Dantan and Å. Johansson (2009)"Intergenerational Social Mobility in European OECD Countries", OECD Economics Department Working Paper No: 709.

Checchi, D. and L. Flabbi (2006) "Intergenerational Mobility and Schooling Decisions in Italy and Germany: the Impact of Secondary School Tracks", Bonn: Institute for the Study of Labor (IZA) Discussion Paper No: 2348.

Checchi, D., C. Fiorio, and M. Leonardi (2008) "Intergenerational Persistence in Educational Attainment in Italy", Bonn: Institute for the Study of Labor (IZA) Discussion Paper No: 3622 .

Checchi D., A, Ichino and A. Rustichini (1999) "More Equal But Less Mobile? Educational Financing and Intergenerational Mobility in Italy and in the US", Journal of Public Economics , 71, 351-393. 
Chevalier, A. (2004) "Parental Education and Child's Education: A Natural Experiment", Institute for the Study of Labor (IZA) Discussion Paper No: 1153.

Chevalier, A., K. Denny, and M. McMahon (2007) "A Multi-Country Study of Inter-generational Educational Mobility", In Education and inequality across Europe. Edward Elgar.

Comi, S. (2004) "Intergenerational Mobility in Europe: Evidence from ECHP", Munich: CESIfo Conference on Schooling and Human Capital Formation in the Global Economy.

Daouli, Joan, Michael Demoussis and Nicholas Giannokopoulos (2010) "Mothers Fathers and Daughters: Intergenerational Transmission of Education in Greece", Economics of Education Review, 29(1): 83-93.

Di Paolo, Antonio (2011) "Parental Education and Familly Characteristics: Educational Opportunities Across Cohorts in Italy and Spain", Document de Treball, XREAP2010-5.

Farré, L., R. Klein and F. Vella (2012) "Does Increasing Parents' Schooling Raise the Schooling of the Next Generation? Evidence Based on Conditional Second Moments", Oxford Bulletin of Economics and Statistics, Forthcoming.

Ferreira, F., J. Gignoux and M. Aran (2009) "Inequality of Economic Opportunity in Turkey", Ankara: SPO-World Bank Welfare and Social Policy Working Paper No: 3.

Ferreira, F. and J. Gignoux (2009) "Inequality of Opportunity for Education: The case of Turkey", Ankara: SPO-World Bank Welfare and Social Policy Working Paper No: 4.

Education Reform Initiative (2009) “Inequality of Opprotunities in Education”, İstanbul: Eğitim Reformu Girişimi.

de Haan, M. (2008) "The Effect of Parents' Schooling on Child's Schooling A Nonparametric Bounds Analysis", Amsterdam: Tinbergen Institute Discussion Paper No: TI 2008-061/3.

Haveman, R., and B. Wolfe (1995) "The Determinants of Children's Attainments: A Review of Methods and Findings", Journal of Economic Literature, 33: 1829-1878.

Heineck, G. and R. T. Riphahn (2009) "Intergenerational Transmission of Educational Attainment in Germany - The Last Five Decades", Jahrbücher für Nationalökonomie und Statistik, 229(1): 36-60.

Helmuth C., P. De Donder and P. Pestieau (2009) "Education and Social Mobility", CESifo Working Paper No: 2951.

Holmlund, H., M. Lindahl, and E. Plug (2008) "Estimating the Intergenerational Schooling Effect: A Comparison of Methods", Bonn: Institute for the Study of Labor (IZA) Discussion Paper No: 3630.

Holmlund, H., M. Lindahl, and E. Plug (2011) "The Causal Effect of Parents' Schooling on Children's Schooling: A Comparison of Estimation Methods," Journal of Economic Literature, 49(3): 615-651.

Hertz, T., T. Jayasundera, P. Piraino, S. Selcuk, N. Smith, and A. Verashchagina (2008) " The Inheritance of Educational Inequality: International Comparisons and Fifty-Year Trends", Advances in Economic Analysis and Policy 7(2), 1775.1775.

Iannelli, C. and L. Paterson (2005) "Does Education Promote Social Mobility?",CES Briefings No. 35, Edinburgh.

Lauer, Charlotte (2003) "Family Background, Cohort and Education: A French-German Comparison Based on a Multivariate Ordered Probit Model of Educational Attainment", Labour Economics 10(2), 231-251.

Lillard, L. A., \& Willis, R. J. (1994) "Intergenerational Educational Mobility: Effects of Family and State in Malaysia", Journal of Human Resources, 29(4): 1126-1166. 
Machin, Stephen and Anna Vignoles (2004) "Educational Inequality: The Widening SocioEconomic Gap", Fiscal Studies 25(2), 107-128.

Mejia, D. and M. St-Pierre (2008) "Unequal Opportunities and Human Capital Formation", Journal of Development Economics, 86(2), 395-413.

Niknami, Susan (2010) "Intergenerational Transmission of Education among Immigrant Mothers and their Daughters in Sweden", Stockholm: The Stockholm University, Linnaeus Center for Integration Studies Working Paper No: 2010:10.

Nimubona, A. D. and D. Vencatachellum (2007) "Intergenerational Education Mobility of Black and White South Africans", Journal of Population Economics, 20:149-182.

Oreopoulos, Philip, Marianne E. Page, and Ann Huff Stevens (2006) "The Intergenerational Effects of Compulsory Schooling", Journal of Labor Economics, 24(4), 729-760.

Oosterbeek, H. (1995) "Choosing the Optimum Mix of Duration and Effort in Education", Economics of Education Review, 14 (3) : 253-263.

Paes de Barros, R., F. Ferreira, J. Molinas Vega and J. S. Chanduvi (2009) “ Measuring Inequality of Opportunities in Latin America and the Caribbean", Washington, DC: Latin American Development Forum Series.

Pascual, M. (2009) "Intergenerational Income Mobility: The Transmission of Socioeconomic Status in Spain", Journal of Policy Modeling, 31: 835-846.

Pereira, P. T. (2010) Intergenerational Transmission of Education: An Alert to Empirical Implementation “, Bonn: Institute for the Study of Labor (IZA) Discussion Paper No: 5074.

Plug, E. (2004) "Estimating the Effect of Mother's Schooling on Children's Education Using a Sample of Adoptees", American Economic Review, 94(1): 358-368.

Plug, E., and W. Vijverberg (2003) "Schooling, Family Background, and Adoption: Is It Nature or Is It Nurture?", Journal of Political Economy, 111(3): 611-641.

Prais, S. J. (1955) "Measuring Social Mobility", Journal of the Royal Statistical Society, Series A, 118, 56-66.

Pronzato, C. (2012) "An Examination of Paternal and Maternal Intergenerational Transmission of Schooling", Journal of Population Economics, 25(2): 591-608.

Rosenzweig, M., and K. Wolpin (1994) "Inequality among Young Adult Siblings, Public Assistance Programs, and Intergenerational Living Arrangements", Journal of Human Resources, 29(4): 1101-1125.

Rumberger, R.W. (2010) "Education and the Reproduction of Economic Inequality in the United States: An Empirical Investigation", Economics of Education Review, 29(2): 246-254.

Sapelli, C. (2009) "The Evolution of the Intergenerational Mobility of Education in Chile by Cohorts: Facts and Possible Causes", Santiago, Chile: Pontificia Universidad Catolica de Chile, Instituto de Economia Working Paper No: 348.

Sacerdote, B. (2002) "The Nature and Nurture of Economic Outcomes", American Economic Review, 92(2), 344-348.

Schuetz, Gabriela, Heinrich W. Ursprung, and Ludger Woessmann, (2005) "Education Policy and Equality of Opportunity", Munich: CESifo Working Paper No. 1518.

Sen, Anindya and Anthony, Clemente (2010) "Intergenerational Correlations in Educational Attainment: Birth Order and Family Size Effects Using Canadian Data", Economics of Education Review, 29(1): 147-155. 
Schultz, T. Paul (2002) "Why Governments Should Invest More to Educate Girls",World Development, 30(2): 207-225.

Shorrocks, A. F. (1978) “The Measurement of Mobility”, Econometrica, 46: 1013-1024.

Silles, Mary, A. (2011) "Intergenerational Effects of Parental Scchooling on the Cognitive and Non-Cognitive Development of Children", Economics of Education Review, 30(2): 258268.

Solon, Gary (1999) "Intergenerational Mobility in the Labor Market", In Handbook of Labor Economics, Vol. 3, O. Ashenfelter and D. Card (editors). Amsterdam: Elsevier Science B.V.

Tansel, Aysit (2002) "Determinants of School Attainment of Boys and Girls in Turkey: Individual, Household and Community Factors", Economics of Education Review, 21(5): 455-470.

Woessmann, Ludger, (2004) "How Equal are Educational Opportunities? Family Background and Student Achievement in Europe and the United States", Munich: CESifo Working Paper No: 1162. 
Table 1: Highest Degree Completed by Cohort (Children, \%)

\begin{tabular}{|c|r|r|r|r|r|r|r|r|}
\hline cohort & $\begin{array}{c}\text { illiterate } \\
\text { (0 years) }\end{array}$ & $\begin{array}{c}\text { literate } \\
\text { (2 years) }\end{array}$ & $\begin{array}{c}\text { primary } \\
\text { (5 years })\end{array}$ & $\begin{array}{c}\text { middle } \\
(8 \text { years })\end{array}$ & $\begin{array}{c}\text { high school } \\
\text { (11 years })\end{array}$ & $\begin{array}{c}\text { university } \\
(15 \text { years })\end{array}$ & $\begin{array}{c}\text { number of } \\
\text { observation }\end{array}$ & $\begin{array}{c}\text { average } \\
\text { years of } \\
\text { education }\end{array}$ \\
\hline $18-24$ & 4.0 & 8.1 & 17.9 & 21.0 & 41.0 & 7.9 & 5,867 & 8.44 \\
\hline $25-34$ & 4.5 & 2.8 & 44.1 & 10.9 & 23.2 & 14.5 & 9,615 & 7.86 \\
\hline $35-44$ & 7.2 & 4.4 & 53.5 & 10.6 & 14.4 & 9.9 & 8,282 & 6.69 \\
\hline $45-54$ & 12.4 & 7.0 & 51.4 & 7.3 & 13.0 & 8.9 & 6,908 & 6.06 \\
\hline $55-64$ & 22.7 & 12.2 & 45.1 & 5.8 & 7.0 & 7.1 & 4,514 & 4.8 \\
\hline $65+$ & 40.5 & 19.3 & 31.7 & 2.7 & 3.2 & 2.6 & 4,292 & 2.93 \\
\hline
\end{tabular}

Table 2: Highest Degree Completed by Cohort (Mothers, \%)

\begin{tabular}{|c|r|r|r|r|r|r|r|r|}
\hline cohort & $\begin{array}{c}\text { unknown } \\
\text { (0 years })\end{array}$ & $\begin{array}{c}\text { non- } \\
\text { graduate } \\
\text { (1 years })\end{array}$ & $\begin{array}{c}\text { primary } \\
(5 \text { years })\end{array}$ & $\begin{array}{c}\text { middle } \\
(8 \text { years })\end{array}$ & $\begin{array}{l}\text { high school } \\
(11 \text { years })\end{array}$ & $\begin{array}{c}\text { university } \\
(15 \text { years })\end{array}$ & $\begin{array}{c}\text { number of } \\
\text { observation }\end{array}$ & $\begin{array}{c}\text { average } \\
\text { years of } \\
\text { education }\end{array}$ \\
\hline $18-24$ & 0.1 & 38.3 & 48.5 & 5.0 & 5.6 & 2.5 & 5,867 & 4.2 \\
\hline $25-34$ & 0.2 & 48.5 & 43.9 & 3.3 & 2.8 & 1.4 & 9,615 & 3.46 \\
\hline $35-44$ & 0.3 & 63.4 & 32.6 & 1.8 & 1.3 & 0.5 & 8,282 & 2.63 \\
\hline $45-54$ & 0.5 & 71.0 & 25.6 & 1.6 & 1.0 & 0.3 & 6,908 & 2.27 \\
\hline $55-64$ & 0.8 & 80.4 & 16.5 & 1.1 & 1.0 & 0.2 & 4,514 & 1.86 \\
\hline $65+$ & 1.5 & 90.5 & 6.7 & 0.6 & 0.5 & 0.1 & 4,292 & 1.36 \\
\hline
\end{tabular}

Table 3: Highest Degree Completed by Cohort (Fathers, \%)

\begin{tabular}{|c|r|r|r|r|r|r|r|r|}
\hline cohort & $\begin{array}{c}\text { unknown } \\
\text { (0 years })\end{array}$ & $\begin{array}{c}\text { non- } \\
\text { graduate } \\
\text { (1 years })\end{array}$ & $\begin{array}{c}\text { primary } \\
(5 \text { years })\end{array}$ & $\begin{array}{c}\text { middle } \\
(8 \text { years })\end{array}$ & $\begin{array}{c}\text { high school } \\
(11 \text { years })\end{array}$ & $\begin{array}{c}\text { university } \\
(15 \text { years })\end{array}$ & $\begin{array}{c}\text { number of } \\
\text { observation }\end{array}$ & $\begin{array}{c}\text { average } \\
\text { years of } \\
\text { education }\end{array}$ \\
\hline $18-24$ & 0.1 & 16.4 & 56.2 & 10.3 & 10.9 & 6.1 & 5,867 & 5.91 \\
\hline $25-34$ & 0.3 & 23.1 & 58.8 & 7.0 & 6.5 & 4.2 & 9,615 & 5.08 \\
\hline $35-44$ & 0.5 & 38.0 & 52.5 & 3.7 & 3.3 & 2.0 & 8,282 & 3.96 \\
\hline $45-54$ & 0.8 & 48.9 & 42.6 & 3.3 & 2.8 & 1.6 & 6,908 & 3.43 \\
\hline $55-64$ & 1.3 & 63.2 & 29.8 & 2.5 & 1.9 & 1.3 & 4,514 & 2.73 \\
\hline $65+$ & 1.9 & 80.5 & 13.2 & 1.7 & 1.7 & 0.9 & 4,292 & 1.93 \\
\hline
\end{tabular}


Table 4: Markov Educational Transition Matrix

\begin{tabular}{|c|c|c|c|c|c|c|c|}
\hline \multirow{2}{*}{\multicolumn{2}{|c|}{ Markov Transition Matrix }} & \multicolumn{5}{|c|}{ Children } & \multirow{2}{*}{ Total } \\
\hline & & $\begin{array}{l}\text { 1) Illiterate } \\
\text { and literate but }\end{array}$ & 2) Graduate & $\begin{array}{l}\text { 3) Graduate of } \\
\text { middle school }\end{array}$ & 4)Graduate & 5) Graduate & \\
\hline \multirow{5}{*}{ Parent } & $\begin{array}{l}\text { 1) Illiterate and literate } \\
\text { but not graduate of any } \\
\text { school. }\end{array}$ & 40,18 & 45,33 & 5,66 & 6,22 & 2,61 & 100 \\
\hline & $\begin{array}{l}\text { 2) Graduate of primary } \\
\text { school }\end{array}$ & 6,66 & 47,94 & 14,11 & 21,95 & 9,34 & 100 \\
\hline & $\begin{array}{l}\text { 3) Graduate of middle } \\
\text { school or } 8 \text { year } \\
\text { education }\end{array}$ & 2,81 & 17,75 & 17,35 & 41,32 & 20,76 & 100 \\
\hline & $\begin{array}{l}\text { 4) Graduate of high } \\
\text { school }\end{array}$ & 1,64 & 9,61 & 8,87 & 47,73 & 32,15 & 100 \\
\hline & $\begin{array}{l}\text { 5) Graduate of } \\
\text { university or above. }\end{array}$ & 0,70 & 3,51 & 3,69 & 40,91 & 51,19 & 100 \\
\hline
\end{tabular}

Table 5: Standard Deviation of Education of Children, Mothers and Fathers with Their Ratio

\begin{tabular}{|c|c|c|c|c|c|}
\hline cohort & $\sigma_{\mathrm{c}}$ & $\sigma_{\mathrm{m}}$ & $\sigma_{\mathrm{f}}$ & $\sigma_{\mathrm{c} /} \sigma_{\mathrm{m}}$ & $\sigma_{\mathrm{c}} / \sigma_{\mathrm{f}}$ \\
\hline $18-24$ & 0.05 & 0.04 & 0.05 & 1.18 & 1.07 \\
\hline $25-34$ & 0.04 & 0.03 & 0.03 & 1.45 & 1.25 \\
\hline $35-44$ & 0.04 & 0.03 & 0.03 & 1.64 & 1.33 \\
\hline $45-54$ & 0.05 & 0.03 & 0.04 & 1.86 & 1.41 \\
\hline $55-64$ & 0.06 & 0.03 & 0.04 & 2.09 & 1.50 \\
\hline $65+$ & 0.05 & 0.02 & 0.04 & 2.42 & 1.44 \\
\hline
\end{tabular}


Table 6: Intergenerational Educational Coefficient

\begin{tabular}{|c|c|c|c|c|c|}
\hline cohort & & Mother & Mother* & Father & Father* \\
\hline \multirow{3}{*}{$18-24$} & $\hat{\beta}$ & 0.522 & 0.483 & 0.497 & 0.461 \\
\hline & $\sigma$ & 0.014 & 0.014 & 0.012 & 0.012 \\
\hline & $\mathrm{R}^{2}$ adj & 0.196 & 0.237 & 0.217 & 0.256 \\
\hline \multirow{3}{*}{$25-34$} & $\hat{\beta}$ & 0.608 & 0.577 & 0.619 & 0.592 \\
\hline & $\sigma$ & 0.013 & 0.013 & 0.011 & 0.011 \\
\hline & $\mathrm{R}^{2}$ adj & 0.176 & 0.231 & 0.246 & 0.297 \\
\hline \multirow{3}{*}{$35-44$} & $\hat{\beta}$ & 0.599 & 0.570 & 0.600 & 0.579 \\
\hline & $\sigma$ & 0.017 & 0.016 & 0.013 & 0.013 \\
\hline & $\mathrm{R}^{2}$ adj & 0.134 & 0.201 & 0.203 & 0.266 \\
\hline \multirow{3}{*}{$45-54$} & $\hat{\beta}$ & 0.754 & 0.681 & 0.667 & 0.612 \\
\hline & $\sigma$ & 0.020 & 0.019 & 0.015 & 0.014 \\
\hline & $\mathrm{R}^{2}$ adj & 0.164 & 0.283 & 0.225 & 0.335 \\
\hline \multirow{3}{*}{$55-64$} & $\hat{\beta}$ & 0.871 & 0.761 & 0.719 & 0.646 \\
\hline & $\sigma$ & 0.028 & 0.026 & 0.020 & 0.018 \\
\hline & $\mathrm{R}^{2}$ adj & 0.173 & 0.325 & 0.230 & 0.374 \\
\hline \multirow{3}{*}{$65+$} & $\hat{\beta}$ & 0.967 & 0.880 & 0.681 & 0.627 \\
\hline & $\sigma$ & 0.034 & 0.031 & 0.019 & 0.018 \\
\hline & $\mathrm{R}^{2}$ adj & 0.159 & 0.304 & 0.224 & 0.357 \\
\hline
\end{tabular}

* controlled for sex and region 
Table 7: Intergenerational Educational Correlation Coefficient

\begin{tabular}{|c|c|c|c|c|c|}
\hline cohort & & Mother & Mother* & Father & Father* \\
\hline \multirow{3}{*}{$18-24$} & $\hat{\beta}$ & 0.417 & 0.386 & 0.497 & 0.461 \\
\hline & $\sigma$ & 0.011 & 0.011 & 0.012 & 0.012 \\
\hline & $\mathrm{R}^{2}$ adj & 0.196 & 0.237 & 0.217 & 0.256 \\
\hline \multirow{3}{*}{$25-34$} & $\hat{\beta}$ & 0.456 & 0.433 & 0.464 & 0.444 \\
\hline & $\sigma$ & 0.010 & 0.010 & 0.008 & 0.008 \\
\hline & $\mathrm{R}^{2}$ adj & 0.176 & 0.231 & 0.246 & 0.297 \\
\hline \multirow{3}{*}{$35-44$} & $\hat{\beta}$ & 0.449 & 0.427 & 0.450 & 0.434 \\
\hline & $\sigma$ & 0.013 & 0.012 & 0.010 & 0.010 \\
\hline & $\mathrm{R}^{2}$ adj & 0.134 & 0.201 & 0.203 & 0.266 \\
\hline \multirow{3}{*}{$45-54$} & $\hat{\beta}$ & 0.452 & 0.409 & 0.534 & 0.489 \\
\hline & $\sigma$ & 0.012 & 0.012 & 0.012 & 0.011 \\
\hline & $\mathrm{R}^{2}$ adj & 0.164 & 0.283 & 0.225 & 0.335 \\
\hline \multirow{3}{*}{$55-64$} & $\hat{\beta}$ & 0.436 & 0.380 & 0.230 & 0.431 \\
\hline & $\sigma$ & 0.014 & 0.013 & 0.479 & 0.012 \\
\hline & $\mathrm{R}^{2}$ adj & 0.173 & 0.325 & 0.013 & 0.374 \\
\hline \multirow{3}{*}{$65+$} & $\hat{\beta}$ & 0.387 & 0.352 & 0.545 & 0.502 \\
\hline & $\sigma$ & 0.014 & 0.013 & 0.015 & 0.014 \\
\hline & $\mathrm{R}^{2}$ adj & 0.159 & 0.304 & 0.224 & 0.357 \\
\hline
\end{tabular}

* controlled for sex and region 
Table 8: Intergenerational Educational Coefficient for Mother by Educational Background

\begin{tabular}{|c|c|c|c|c|c|}
\hline Cohort & & $\begin{array}{c}\text { Mother } \\
\text { (primary or less) }\end{array}$ & $\begin{array}{c}\text { Mother* } \\
\text { ( primary or less) }\end{array}$ & $\begin{array}{c}\text { Mother } \\
\text { (post primary) }\end{array}$ & $\begin{array}{c}\text { Mother* } \\
\text { (post primary) }\end{array}$ \\
\hline \multirow{3}{*}{$18-24$} & $\hat{\beta}$ & 0.750 & 0.702 & 0.124 & 0.121 \\
\hline & $\sigma$ & 0.025 & 0.024 & 0.032 & 0.032 \\
\hline & $\mathrm{R}^{2}$ adj & 0.153 & 0.204 & 0.019 & 0.023 \\
\hline \multirow{3}{*}{$25-34$} & $\hat{\beta}$ & 0.595 & 0.555 & 0.454 & 0.435 \\
\hline & $\sigma$ & 0.020 & 0.019 & 0.046 & 0.046 \\
\hline & $\mathrm{R}^{2}$ adj & 0.090 & 0.157 & 0.119 & 0.127 \\
\hline \multirow{3}{*}{$35-44$} & $\hat{\beta}$ & 0.540 & 0.504 & 0.516 & 0.502 \\
\hline & $\sigma$ & 0.022 & 0.021 & 0.077 & 0.077 \\
\hline & $\mathrm{R}^{2}$ adj & 0.072 & 0.148 & 0.128 & 0.137 \\
\hline \multirow{3}{*}{$45-54$} & $\hat{\beta}$ & 0.739 & 0.649 & 0.348 & 0.315 \\
\hline & $\sigma$ & 0.026 & 0.024 & 0.098 & 0.098 \\
\hline & $\mathrm{R}^{2}$ adj & 0.107 & 0.239 & 0.056 & 0.073 \\
\hline \multirow{3}{*}{$55-64$} & $\hat{\beta}$ & 0.884 & 0.734 & 0.150 & 0.148 \\
\hline & $\sigma$ & 0.037 & 0.035 & 0.161 & 0.154 \\
\hline & $\mathrm{R}^{2}$ adj & 0.112 & 0.277 & -0.001 & 0.079 \\
\hline \multirow{3}{*}{$65+$} & $\hat{\beta}$ & 1.054 & 0.950 & -0.007 & 0.063 \\
\hline & $\sigma$ & 0.047 & 0.043 & 0.278 & 0.265 \\
\hline & $\mathrm{R}^{2}$ adj & 0.108 & 0.263 & -0.020 & 0.096 \\
\hline \multirow{4}{*}{ Total } & $\hat{\beta}$ & 0.866 & 0.801 & 0.300 & 0.286 \\
\hline & $\sigma$ & 0.010 & 0.010 & 0.026 & 0.026 \\
\hline & $\mathrm{R}^{2}$ adj & 0.156 & 0.241 & 0.059 & 0.068 \\
\hline & $\mathrm{n}$ & 37,333 & 37,333 & 2,145 & 2,145 \\
\hline
\end{tabular}

\footnotetext{
* controlled for sex and region
} 
Table 8: Intergenerational Educational Coefficient for Father by Educational Background

\begin{tabular}{|c|c|c|c|c|c|}
\hline Cohort & & $\begin{array}{c}\text { Father } \\
\text { (primary or less) }\end{array}$ & $\begin{array}{c}\text { Father* } \\
\text { (primary or less) }\end{array}$ & $\begin{array}{c}\text { Father } \\
\text { (post primary) }\end{array}$ & $\begin{array}{c}\text { Father* } \\
\text { (post primary) }\end{array}$ \\
\hline \multirow{3}{*}{$18-24$} & $\hat{\beta}$ & 0.854 & 0.801 & 0.239 & 0.227 \\
\hline & $\sigma$ & 0.032 & 0.031 & 0.025 & 0.025 \\
\hline & $\mathrm{R}^{2}$ adj & 0.142 & 0.196 & 0.053 & 0.064 \\
\hline \multirow{3}{*}{$25-34$} & $\hat{\beta}$ & 0.649 & 0.610 & 0.453 & 0.439 \\
\hline & $\sigma$ & 0.023 & 0.022 & 0.030 & 0.030 \\
\hline & $\mathrm{R}^{2}$ adj & 0.095 & 0.170 & 0.118 & 0.136 \\
\hline \multirow{3}{*}{$35-44$} & $\hat{\beta}$ & 0.524 & 0.503 & 0.481 & 0.453 \\
\hline & $\sigma$ & 0.020 & 0.020 & 0.048 & 0.048 \\
\hline & $\mathrm{R}^{2}$ adj & 0.081 & 0.159 & 0.118 & 0.148 \\
\hline \multirow{3}{*}{$45-54$} & $\hat{\beta}$ & 0.624 & 0.545 & 0.465 & 0.449 \\
\hline & $\sigma$ & 0.023 & 0.021 & 0.058 & 0.057 \\
\hline & $\mathrm{R}^{2}$ adj & 0.107 & 0.241 & 0.106 & 0.160 \\
\hline \multirow{3}{*}{$55-64$} & $\hat{\beta}$ & 0.675 & 0.575 & 0.485 & 0.510 \\
\hline & $\sigma$ & 0.029 & 0.027 & 0.091 & 0.085 \\
\hline & $\mathrm{R}^{2}$ adj & 0.111 & 0.281 & 0.097 & 0.217 \\
\hline \multirow{3}{*}{$65+$} & $\hat{\beta}$ & 0.673 & 0.617 & 0.224 & 0.255 \\
\hline & $\sigma$ & 0.032 & 0.030 & 0.125 & 0.116 \\
\hline & $\mathrm{R}^{2}$ adj & 0.095 & 0.254 & 0.012 & 0.153 \\
\hline \multirow{4}{*}{ Total } & $\hat{\beta}$ & 0.832 & 0.778 & 0.386 & 0.372 \\
\hline & $\sigma$ & 0.010 & 0.009 & 0.018 & 0.017 \\
\hline & $\mathrm{R}^{2}$ adj & 0.176 & 0.262 & 0.088 & 0.112 \\
\hline & $\mathrm{n}$ & 34451 & 34451 & 5027 & 5027 \\
\hline
\end{tabular}

* controlled for sex and region 
Table 10: Intergenerational Educational Coefficient with Alternative Educational Background

\begin{tabular}{|c|c|c|c|c|c|}
\hline cohort & & Mother* & Father* & $\begin{array}{l}\text { Average parental } \\
\text { schooling* }\end{array}$ & $\begin{array}{l}\text { Parent with the } \\
\text { highest education* }\end{array}$ \\
\hline \multirow{3}{*}{$18-24$} & $\beta$ & 0.275 & 0.312 & 0.589 & 0.469 \\
\hline & $\sigma$ & 0.017 & 0.015 & 0.014 & 0.012 \\
\hline & $\mathrm{R}^{2}$ adj & 0.290 & 0.290 & 0.290 & 0.268 \\
\hline \multirow{3}{*}{$25-34$} & $\hat{\beta}$ & 0.257 & 0.461 & 0.737 & 0.593 \\
\hline & $\sigma$ & 0.015 & 0.013 & 0.013 & 0.011 \\
\hline & $\mathrm{R}^{2}$ adj & 0.317 & 0.317 & 0.313 & 0.303 \\
\hline \multirow{3}{*}{$35-44$} & $\hat{\beta}$ & 0.235 & 0.466 & 0.730 & 0.583 \\
\hline & $\sigma$ & 0.019 & 0.016 & 0.016 & 0.013 \\
\hline & $\mathrm{R}^{2}$ adj & 0.279 & 0.279 & 0.274 & 0.273 \\
\hline \multirow{3}{*}{$45-54$} & $\hat{\beta}$ & 0.295 & 0.473 & 0.798 & 0.617 \\
\hline & $\sigma$ & 0.023 & 0.018 & 0.018 & 0.014 \\
\hline & $\mathrm{R}^{2}$ adj & 0.350 & 0.350 & 0.348 & 0.014 \\
\hline \multirow{3}{*}{$55-64$} & $\hat{\beta}$ & 0.309 & 0.502 & 0.849 & 0.641 \\
\hline & $\sigma$ & 0.033 & 0.024 & 0.023 & 0.018 \\
\hline & $\mathrm{R}^{2}$ adj & 0.386 & 0.386 & 0.384 & 0.376 \\
\hline \multirow{3}{*}{$65+$} & $\hat{\beta}$ & 0.412 & 0.483 & 0.917 & 0.632 \\
\hline & $\sigma$ & 0.037 & 0.022 & 0.025 & 0.018 \\
\hline & $\mathrm{R}^{2}$ adj & 0.375 & 0.375 & 0.375 & 0.365 \\
\hline \multirow{4}{*}{ Total } & $\hat{\beta}$ & 0.302 & 0.513 & 0.842 & 0.669 \\
\hline & $\sigma$ & 0.009 & 0.007 & 0.006 & 0.005 \\
\hline & $\mathrm{R}^{2}$ adj & 0.383 & 0.383 & 0.379 & 0.371 \\
\hline & $\mathrm{n}$ & 39,478 & 39,478 & 39,478 & 39,478 \\
\hline
\end{tabular}

* controlled for sex and region 
Table 11: Intergenerational Educational Correlation Coefficient by Alternative Definitions of the Educational Background

\begin{tabular}{|l|c|c|c|c|}
\hline & $\hat{\beta}$ & $\sigma$ & $\mathrm{R}^{2}$ adj & $\mathrm{n}$ \\
\hline Mother* (primary or less) & 0.532 & 0.007 & 0.209 & 37333 \\
\hline Mother* (post primary) & 0.302 & 0.018 & 0.118 & 2145 \\
\hline Father* (primary or less) & 0.652 & 0.007 & 0.285 & 34451 \\
\hline Father* (post primary) & 0.411 & 0.011 & 0.242 & 5027 \\
\hline Mother* & 0.161 & 0.006 & 0.395 & 39478 \\
\hline Father* & 0.479 & 0.005 & 0.395 & 39478 \\
\hline Average parental schooling* & 0.669 & 0.005 & 0.380 & 39478 \\
\hline Parent with the highest education* & 0.628 & 0.006 & 0.312 & 39478 \\
\hline
\end{tabular}

* controlled for sex and region

Figure 1: Expected Years of Education across Cohorts by Parental Education

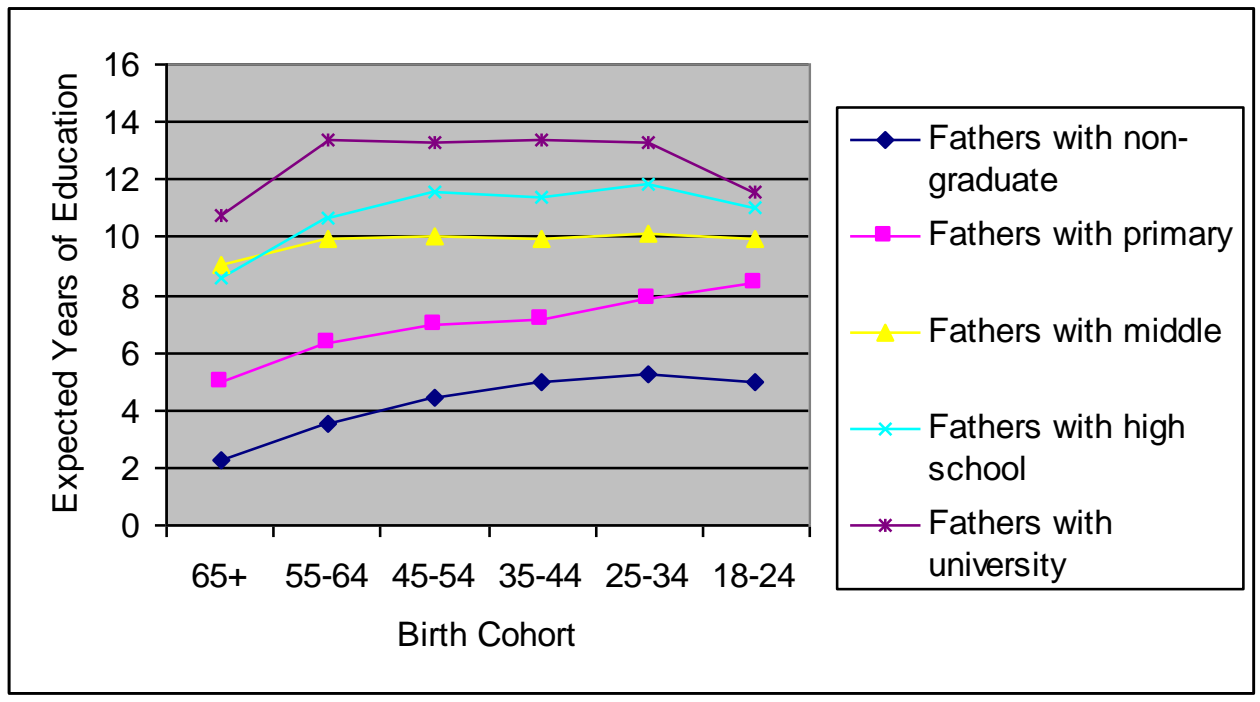


Table 12: Ordered Probit Estimates for Completed Education

\begin{tabular}{|l|c|c|c|c|c|c|c|}
\hline \multicolumn{2}{|c|}{} & $18-24$ & $25-34$ & $35-44$ & $45-54$ & $55-64$ & $65+$ \\
\hline \multirow{3}{*}{ Father_middle } & $\hat{\beta}$ & $\mathbf{0 . 6 6 7}$ & $\mathbf{0 . 8 3 0}$ & $\mathbf{1 . 0 3 5}$ & $\mathbf{1 . 1 2 5}$ & $\mathbf{1 . 2 6 4}$ & $\mathbf{1 . 5 3 8}$ \\
\cline { 2 - 8 } & $\sigma$ & 0.048 & 0.044 & 0.064 & 0.076 & 0.107 & 0.138 \\
\hline \multirow{3}{*}{ Father_high } & $\hat{\beta}$ & $\mathbf{1 . 0 3 1}$ & $\mathbf{1 . 3 0 4}$ & $\mathbf{1 . 3 7 7}$ & $\mathbf{1 . 5 1 5}$ & $\mathbf{1 . 5 1 0}$ & $\mathbf{1 . 5 4 0}$ \\
\cline { 2 - 8 } & $\sigma$ & 0.048 & 0.047 & 0.069 & 0.083 & 0.125 & 0.140 \\
\hline \multirow{3}{*}{ Father_university y } & $\hat{\beta}$ & $\mathbf{1 . 2 4 3}$ & $\mathbf{1 . 8 0 9}$ & $\mathbf{2 . 0 2 7}$ & $\mathbf{2 . 0 5 8}$ & $\mathbf{2 . 3 6 3}$ & $\mathbf{2 . 0 3 9}$ \\
\cline { 2 - 8 } & $\sigma$ & 0.064 & 0.063 & 0.098 & 0.119 & 0.176 & 0.185 \\
\hline \multirow{3}{*}{ Gender } & $\hat{\beta}$ & $\mathbf{0 . 3 0 8}$ & $\mathbf{0 . 4 6 5}$ & $\mathbf{0 . 5 1 7}$ & $\mathbf{0 . 6 5 9}$ & $\mathbf{0 . 7 5 0}$ & $\mathbf{0 . 7 6 4}$ \\
\cline { 2 - 8 } & $\sigma$ & 0.029 & 0.024 & 0.028 & 0.033 & 0.047 & 0.067 \\
\hline \multirow{3}{*}{ Urban } & $\hat{\beta}$ & $\mathbf{0 . 4 1 8}$ & $\mathbf{0 . 4 5 5}$ & $\mathbf{0 . 4 3 8}$ & $\mathbf{0 . 6 7 8}$ & $\mathbf{0 . 7 9 2}$ & $\mathbf{0 . 9 3 1}$ \\
\cline { 2 - 8 } & $\sigma$ & 0.033 & 0.028 & 0.032 & 0.038 & 0.056 & 0.080 \\
\hline \multirow{3}{*}{$\mu_{1}$} & $\boldsymbol{\mu}_{\mathbf{1}}$ & $\mathbf{0 . 0 7 2}$ & $\mathbf{0 . 7 7 9}$ & $\mathbf{1 . 0 9 1}$ & $\mathbf{1 . 5 1 8}$ & $\mathbf{1 . 9 6 8}$ & $\mathbf{2 . 6 3 7}$ \\
\cline { 2 - 8 } & $\sigma$ & 0.031 & 0.028 & 0.033 & 0.040 & 0.059 & 0.089 \\
\hline \multirow{2}{*}{$\mu_{2}$} & $\boldsymbol{\mu}_{\mathbf{2}}$ & $\mathbf{0 . 7 0 7}$ & $\mathbf{1 . 1 0 9}$ & $\mathbf{1 . 4 4 9}$ & $\mathbf{1 . 7 9 8}$ & $\mathbf{2 . 2 6 2}$ & $\mathbf{2 . 9 1 3}$ \\
\cline { 2 - 8 } & $\sigma$ & 0.032 & 0.029 & 0.034 & 0.041 & 0.061 & 0.092 \\
\hline \multirow{2}{*}{$\mu_{3}$} & $\boldsymbol{\mu}_{\mathbf{3}}$ & $\mathbf{2 . 2 8 8}$ & $\mathbf{2 . 0 0 3}$ & $\mathbf{2 . 1 4 4}$ & $\mathbf{2 . 5 0 4}$ & $\mathbf{2 . 7 6 7}$ & $\mathbf{3 . 4 3 3}$ \\
\cline { 2 - 8 } & $\sigma$ & 0.041 & 0.032 & 0.037 & 0.046 & 0.066 & 0.101 \\
\hline Log likelihood & & 6749.279 & 10341.856 & 7698.409 & 5527.289 & 2732.373 & 1296.034 \\
\hline Pseudo-R ${ }^{2}$ & & 0.084 & 0.106 & 0.094 & 0.127 & 0.157 & 0.213 \\
\hline Number of obs. & & 5867 & 9615 & 8282 & 6908 & 4514 & 4292 \\
\hline \multirow{2}{*}{} & & & & & & \\
\hline
\end{tabular}


Figure 2: Predicted Probabilities

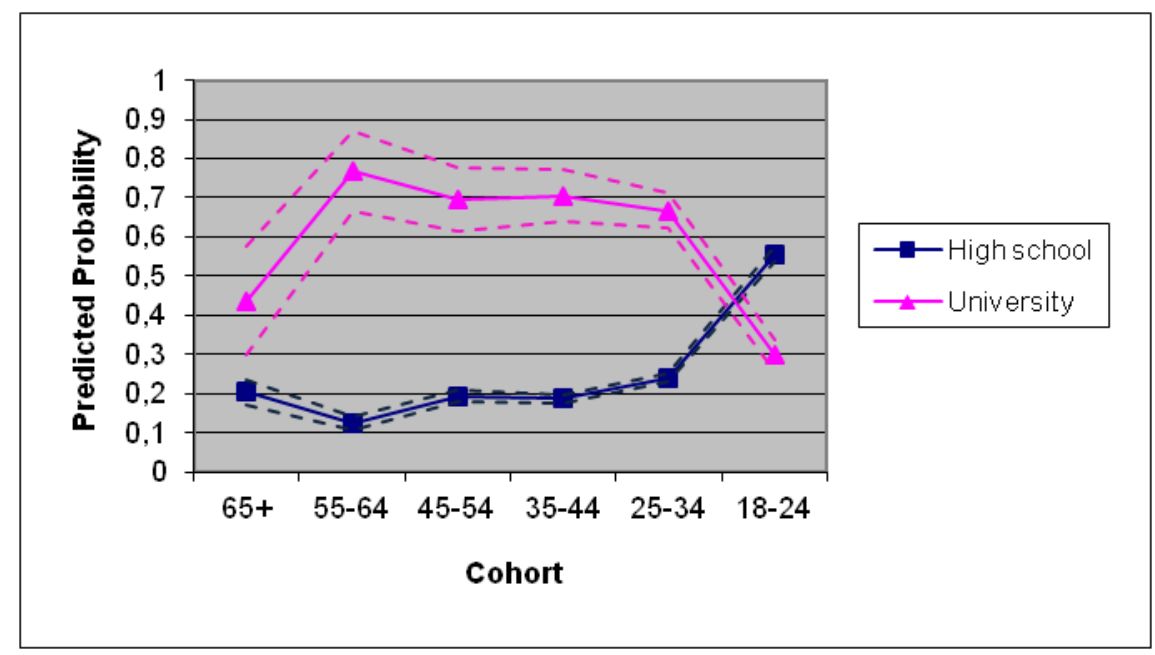

Father Education=University

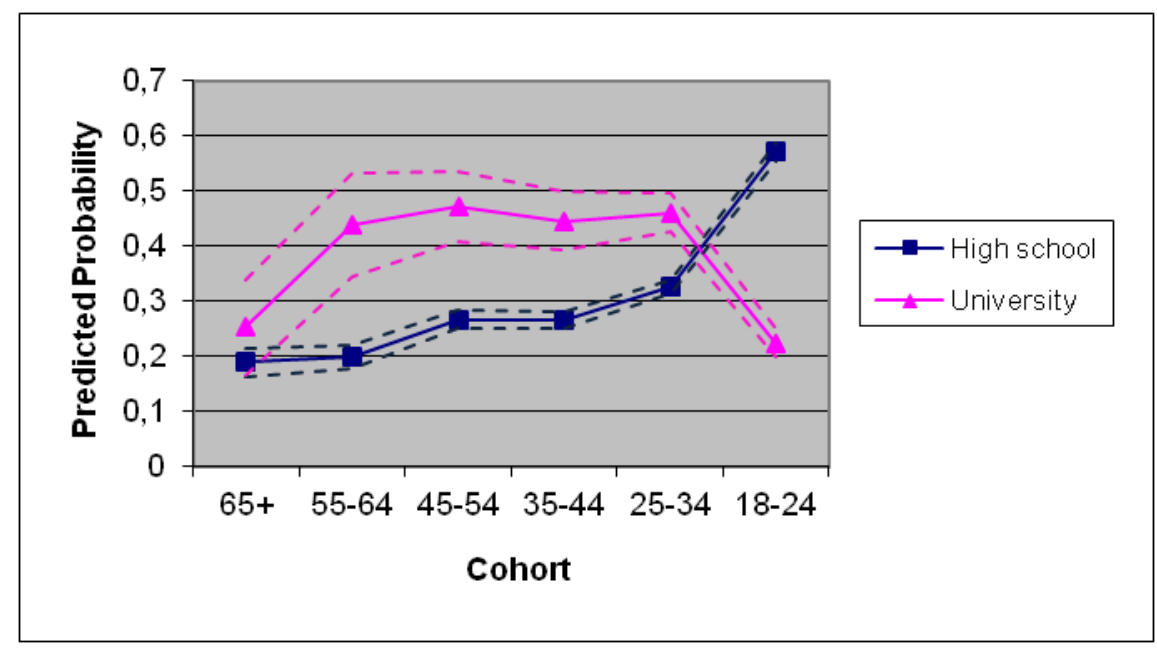

Father Education=High and voc-high school 


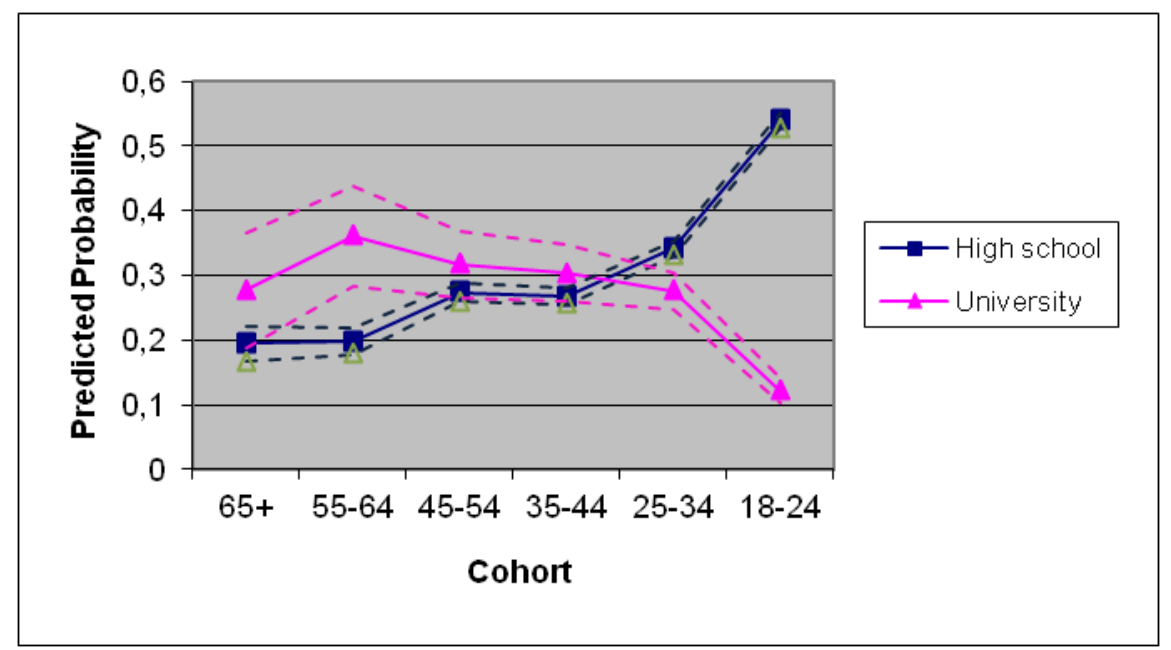

Father Education=Middle school

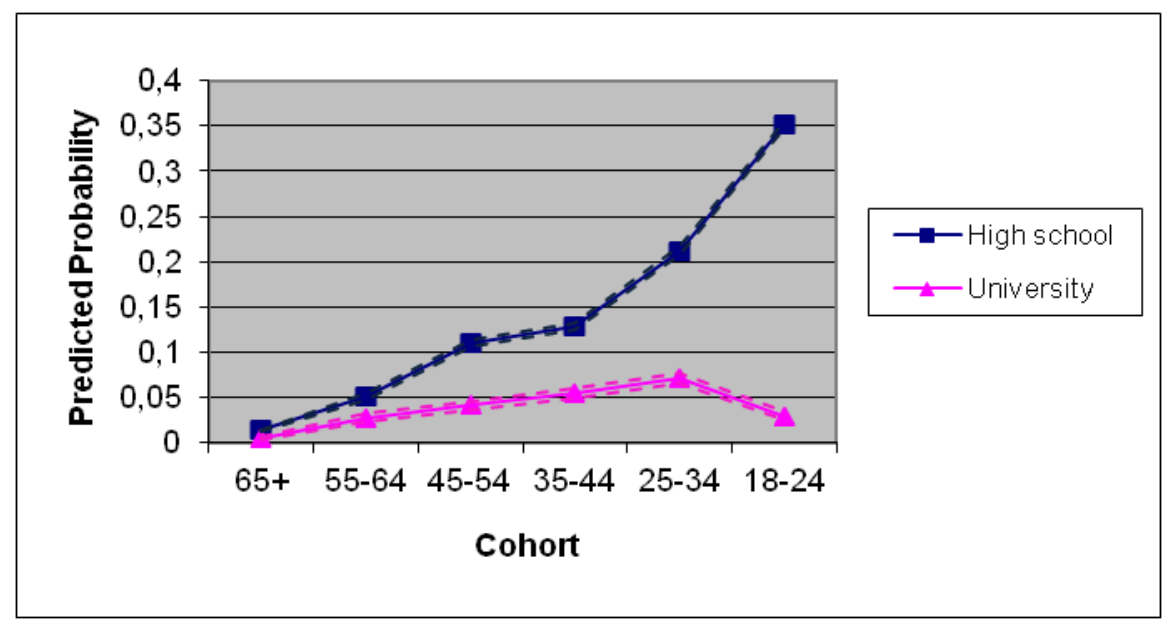

Father Education=Illiterate and primary school 
Figure 3: Predicted Probabilities for Men in Urban Areas

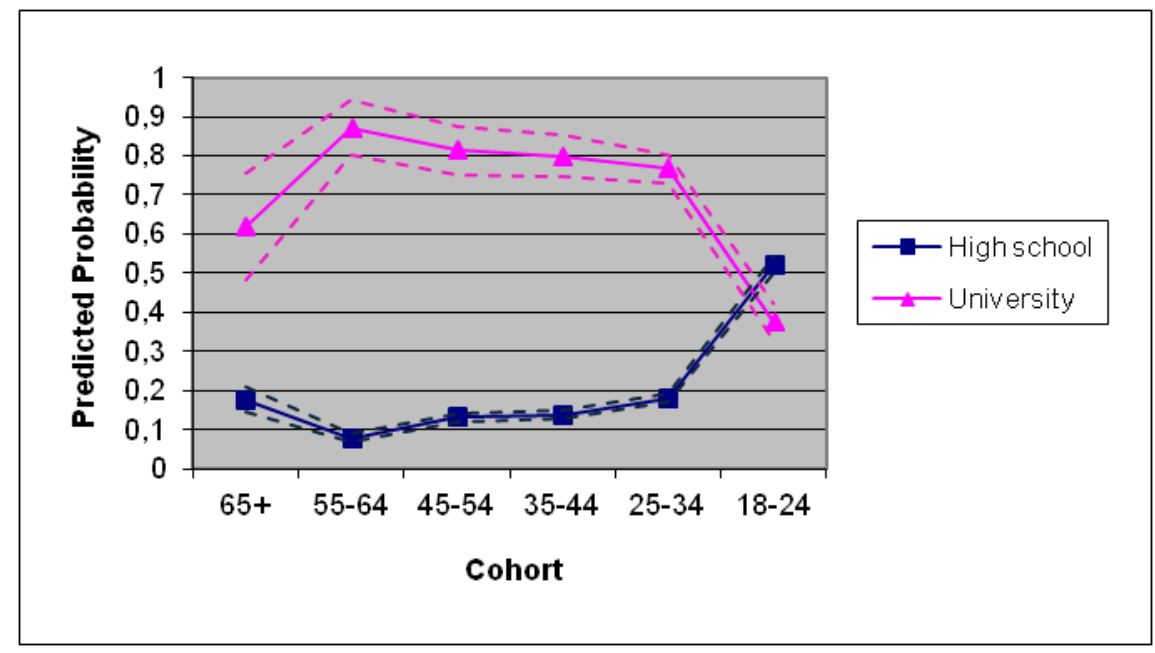

Father Education=University

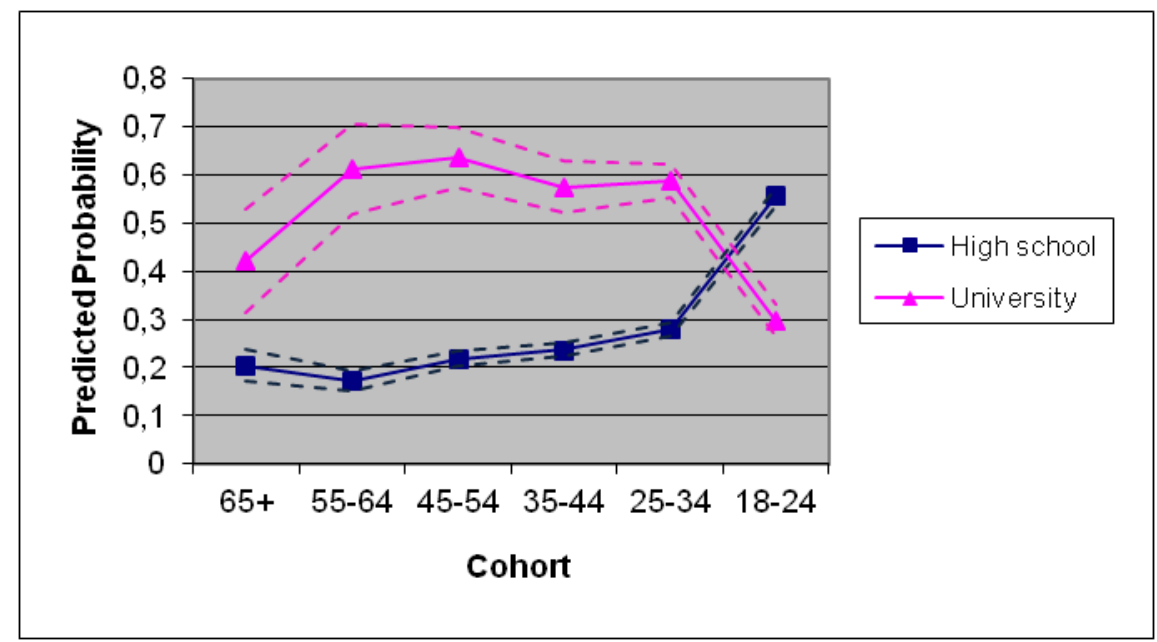

Father Education=High and voc-high school 


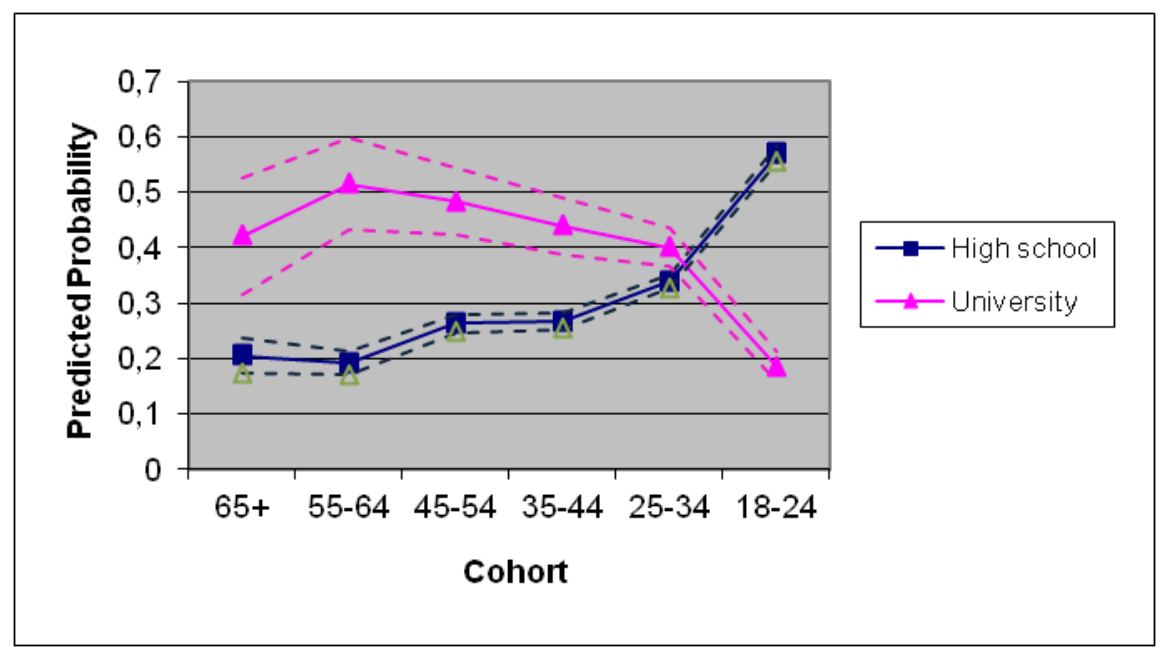

Father Education=Middle school

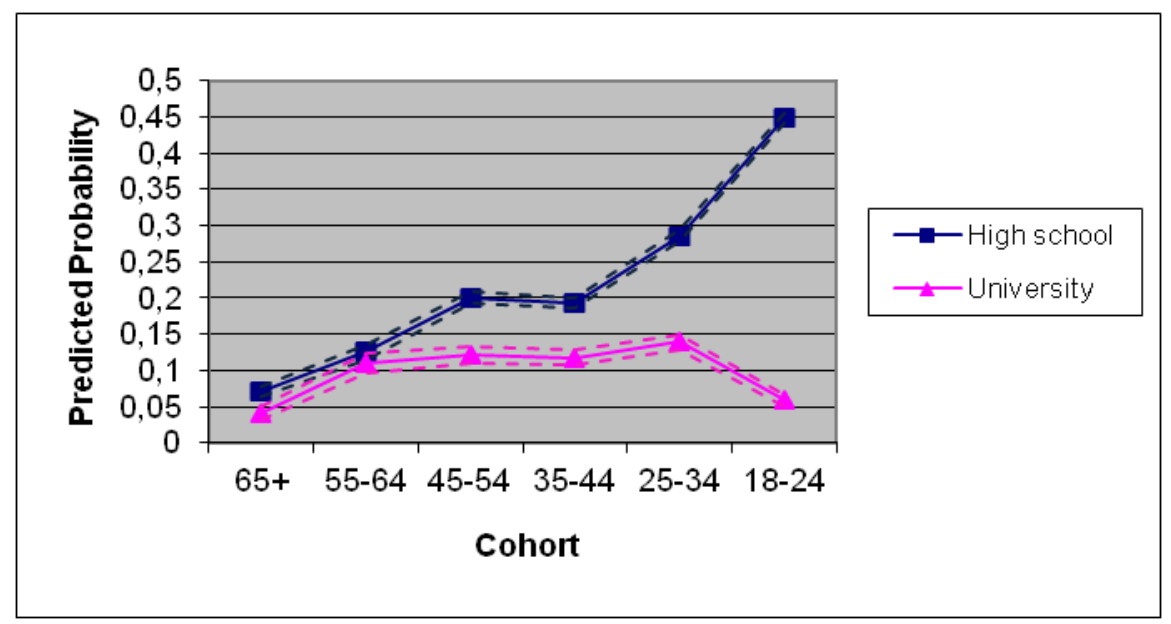

Father Education=Illiterate and primary school 
Figure 4: Predicted Probabilities for Women in Urban Areas

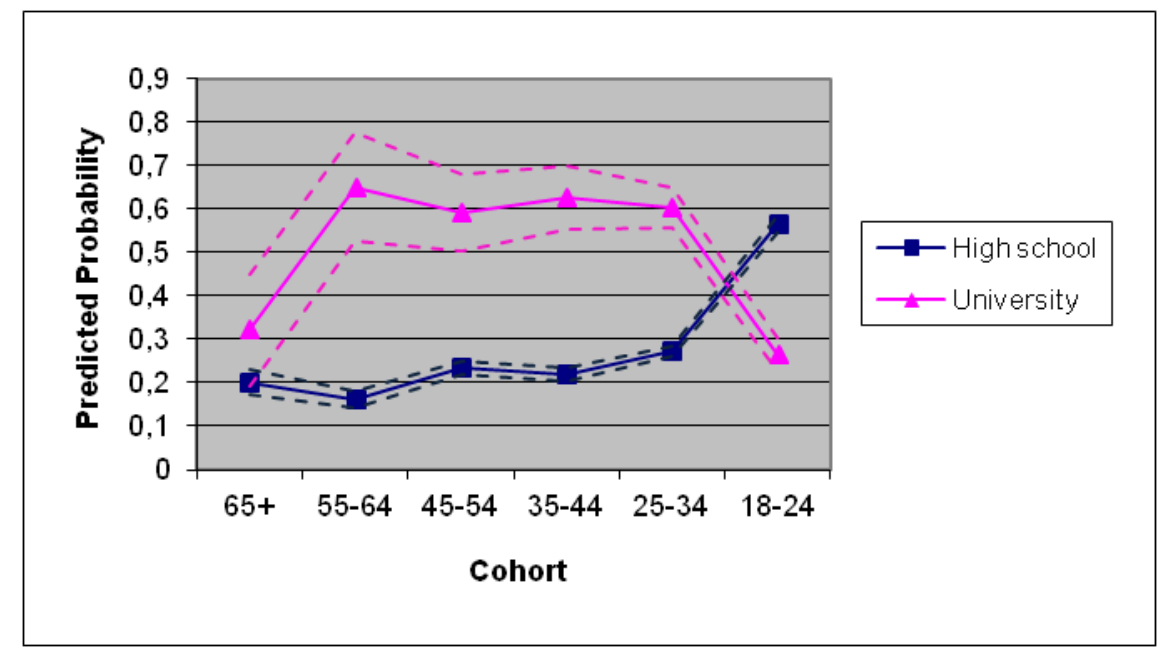

Father Education=University

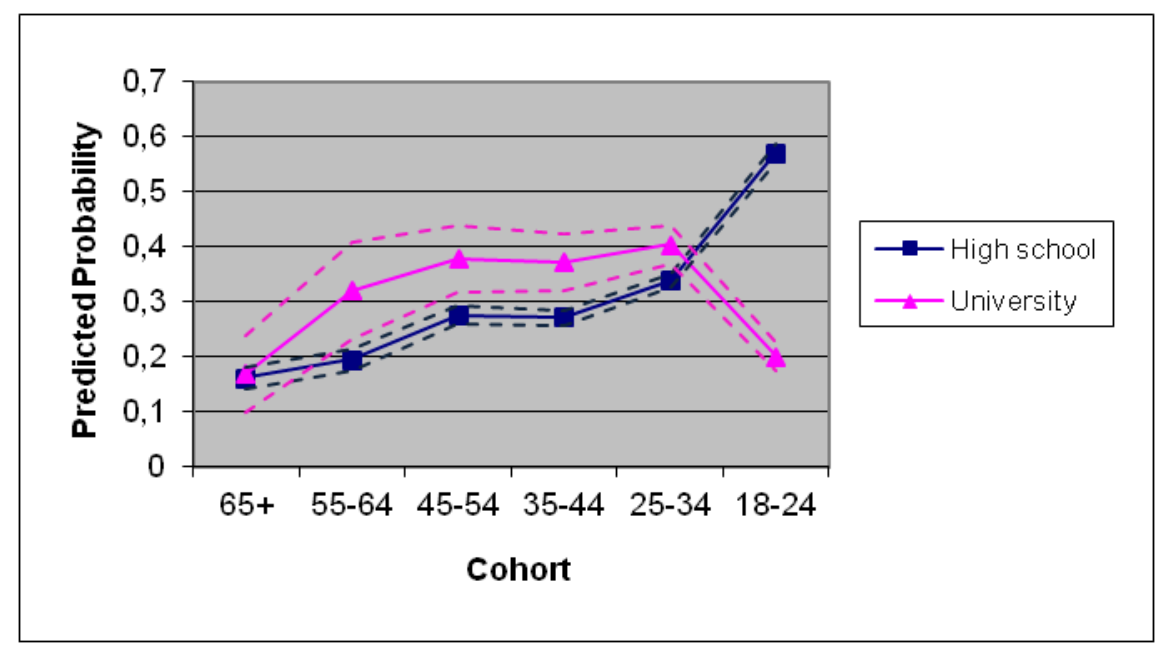

Father Education=High and voc-high school 


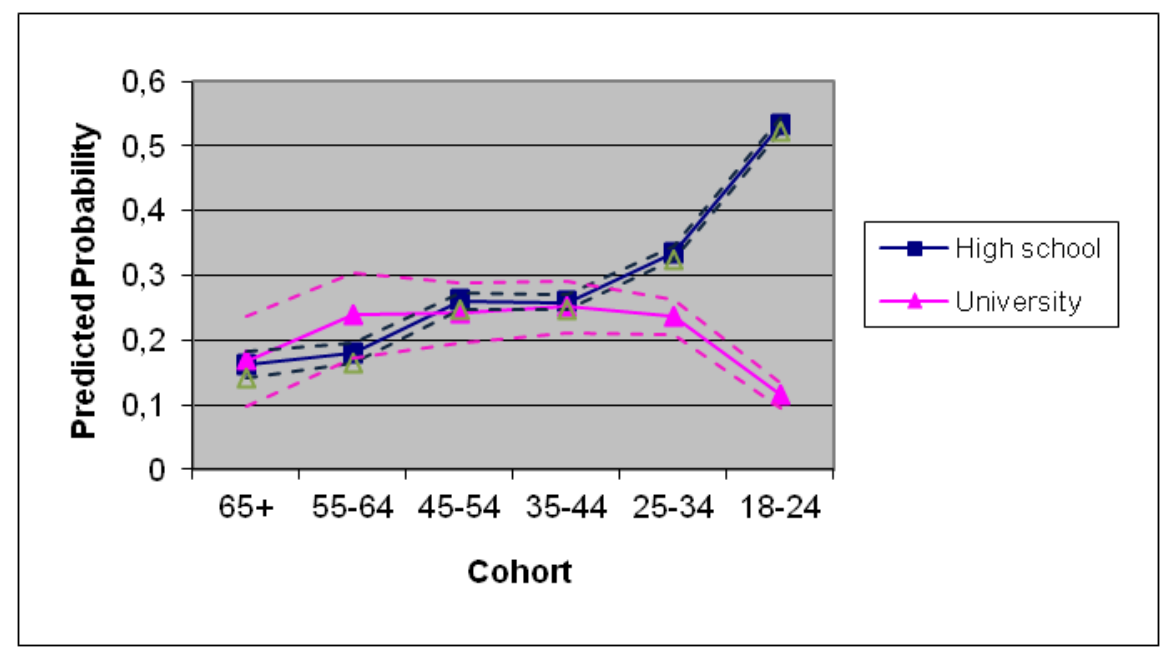

Father Education=Middle school

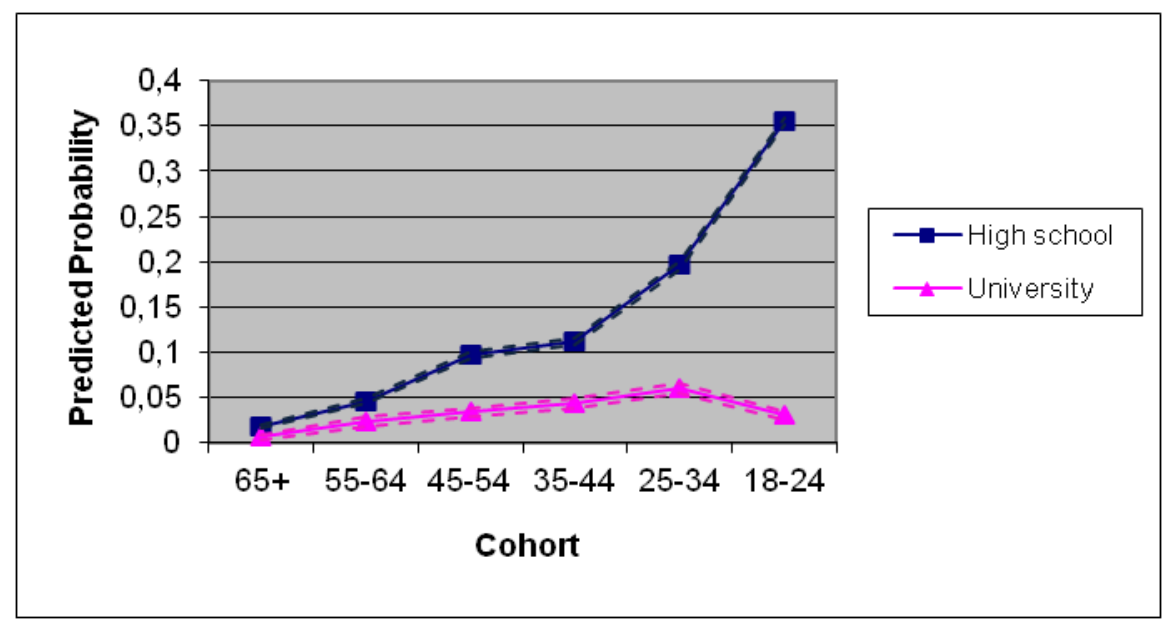

Father Education=Illiterate and primary school 